\title{
PENYEBARAN IKLAN PADA MEDIA ELEKTRONIK YANG MEMUAT KONTEN PORNOGRAFI
}

\author{
Ratu Agung Dewangga Arinatha Gunawan, Nyoman Gede Sugiartha, Ni Made Sukaryati Karma \\ Fakultas Hukum, Universitas Warmadewa, Denpasar-Bali, Indonesia \\ agungdewangga14@gmail.com, nyomansugiartha14@gmail.com, sukariyati64@gmail.com
}

\begin{abstract}
Abstrak
Pemerintah telah mengeluarkan Undang-undang Nomor 44 Tahun 2008 tentang pornografi. Adapun tujuan dari undang-undang tersebut adalah salah satunya memelihara serta mewujudkan kehidupan masyarakat yang beretika, berkepribadian luhur, menjunjung tinggi nilai-nilai Ketuhanan Yang Maha Esa, serta menghormati harkat dan martabat kemanusiaan. Tujuan dari penelitian pengaturan hukum mengenai lklan pornografi pada media sosial dan serta upaya pencegahan terhadap pelaku penyebaran iklan pada media elektronik yang memuat konten pornografi. Jenis penelitian yang gunakan adalah penelitian hukum normatif dengan pendekatan perundang-undangan dan pendekatan konseptual. Sumber bahan hukum yang digunakan terbagi atas bahan hukum primer, sekunder dan tersier. Teknik pengumpulan bahan dalam penelitian menggunakan teknik studi pustaka (library research) yaitu membaca, mencatat, mengutip, meringkas, dan menelaah informasi data dari peraturan atau literatur yang terkait dengan masalah tersebut. Selanjutnya, data yang dikumpulan dianalisis rnenggunakan metode penanganan bahan hukum yang sistematis.
\end{abstract}

Kata Kunci: Iklan, Media, Pornografi

\begin{abstract}
The government has issued Law Number 44 of 2008 concerning pornography. The objectives of this law are, among other things, to maintain and realize social life that is ethical, has a noble personality, upholds the values of the One and Only Godhead, and respects the dignity and dignity of humanity. The purpose of research on legal regulations regarding pornographic advertisements on social media and as well as efforts to prevent perpetrators of spreading advertisements on electronic media containing pornographic content. The type of research used is normative legal research with a statutory approach and a conceptual approach. Sources of legal materials used are divided into primary, secondary and tertiary legal materials. The technique of collecting material in research uses library research techniques, namely reading, taking notes, quoting, summarizing, and examining data information from regulations or literature related to the problem. Furthermore, the data collected was analyzed using a systematic method of handling legal materials.
\end{abstract}

Keywords: Advertising, Media, Pornography

\section{PENDAHULUAN}

Pada era Globalisasi saat ini teknologi informasi (information technology) mempunyai peranan yang sangat penting bagi setiap orang di penjuru dunia, baik yang terjadi pada masa kini maupun yang akan terjadi pada masa depan suatu saat nanti. Saat ini perkembangan teknologi informasi diyakini dapat memberikan keuntungan serta kepentingan yang besar bagi seluruh negara yang ada di dunia. Pada awalnya teknologi informasi diharapkan rnampu untuk menciptakan dan memberikan suatu kemudahan dan kesejahteraan bagi setiap orang dalam kehidupan sehari-hari, saat ini kita lihat dan ketahui bahwa perkembangan teknologi yang sekarang berkembang amat pesat pada zaman modern ini yang dikenal dengan internet (Chazawi \& Ferdian, 2015).

Pada zaman modern yang terjadi saat ini, pengaruh teknologi internet dan media elektronik sudah tidak dapat dipisahkan dari sendi kehidupan masyarakat unruk dapat mengakses suaru informasi. Saat ini terdapat banyak sekali media elektronik yang berlomba-lomba unruk menyampaikan informasi dan berita yang terbaru untuk masyarakat dari golongan muda hingga golongan dewasa. Saat ini media internet dan/atau elektronik yang sering di akses dan banyak digandrungi oleh masyarakat untuk mendapatkan suatu informasi dan berita terbaru, seperti Whatsapp, Line, Youtube, Instagram, Facebook dan lainnya. 
Pada perkembangannya media internet juga dapat digunakan sebagai media penyampaian informasi yang disampaikan dan disematkan melalui sebuah iklan yang terdapat pad a media internet, namun pada dewasa ini, marak diternukan munculnya iklan yang mengandung unsur pornografi yang di tam pi lkan tidak pada tempatnya, dengan kata lain, iklan pornografi sering muncul ketika pengguna internet hendak mengunduh suatu informasi guna keperluan pendidikan maupun keperluan lainnya. Pada masa pandemi virus corona yang melanda seluruh negara di dunia saat ini, khususnya pada dunia pendidikan, seluruh kegiatan belajar dan mengajar yang dilakukan saat ini dilakukan secara daring di rumah masing-masing.

Pada proses belajar dan mengajar yang berlangsung saat masa pandemi virus corona yang terjadi saat ini, seluruh siswa dan/atau siswi dari pendidikan sekolah dasar hingga sekolah menengah atas maupun para mahasiswa dan/atau mahasiswi di perguruan tinggi saat ini yang melakukan kegiatan belajar secara daring, ketika hendak mengunduh suatu materi yang berkaitan dengan pendidikan, sering mereka jumpai suatu iklan di internet yang mengandung unsur pornografi, tentunya hal tersebut memberikan rasa ketidaknyamanan ketika hendak mengunduh suatu materi yang berkaitan dengan tugas-tugas di sekolah maupun di perguruan tinggi.

Di Indonesia, menurut Kepala Humas atau dan Informasi Kemenkominfo Dewa Brata jumlah akses pornografi ini berada di peringkat ketujuh dunia. Menurutnya jumlah akses pornografi di Indonesia saat ini banyak dilakukan oleh kalangan generasi muda, dari anak-anak hingga remaja, saat ini pornografi pada media internet dikemas dalam berbagai macam jenis, dari yang berbentuk majalah, komik hingga video, yang dengan sangat mudah di akses melalui smartphone, komputer, laptop dan lainnya. Hal tersebut sangat memprihatinkan, mengingat di masa pandemi virus corona yang melanda negara di seluruh dunia saat mewajibkan seluruh kegiatan belajar dilakukan dari rumah, yang artinya apabila tidak ada pengawasan dari orangtua terhadap anak ketika menggunakan smartphone, dikhawatirkan terpapar pengaruh iklan pornografi yang sering ditampilkan pada media internet secara bebas (Hamzah, 1989).

Keprihatinan terhadap fenomena pornografi saat ini di tingkat kebijakan oleh negara ditunjukkan dengan adanya upaya pembuatan regulasi hukum guna membatasi pengedaran dan penyebaran sekaligus konsumsinya. Hal ini menjadi produk legal formalnya. Tidak berhenti pada diundangkannya UU No. 44 tahun 2008 tentang Pornografi itu. Pemerintah pun pada saat awal tahun 2012 pernah membentuk dan mendirikan Gugus Satuan Tugas Penanganan dan Pencegahan Pornografi (Satgas Antipornografi) melalui Perpres No. 25 tahun 2012.

Pornografi adalah ancaman yang sangat serius bagi kesalehan terhadap generasi muda dari anak-anak hingga rernaja. Terpapar pornografi sangat berbahaya bagi tumbuh kembang dan pola pikir dari setiap orang, dengan kata lain apabila sudah terpapar pengaruh dari pornografi berarti satu langkah terjerumus kepada kerusakan moral terhadap kelangsungan generasi muda. Paparan pornografi terhadap generasi muda sangat mengkhawatirkan karena dapat merusak pertumbuhan psikologis dan biologis mereka. Terpapar lalu mengkonsurnsi pornografi dapat menyebabkan kecanduan atau keterganrungan anak akan menonton pornografi.

Memahami penyebarluasan pornografi, siapa saja berpotensi terpapar dan dapat terpengaruh pornografi. Dalam hal ini diperlukan peran serta dari orang tua dalam melakukan pengawasan terhadap kegiatan anak pada saat menggunakan media internet, terlebih lagi di masa pandemi virus corona saat ini, yang mengharuskan setiap kegiatan belajar dilakukan secara daring. Peran serta dari orangtua dalarn mengawasi anak-anaknya ketika menggunakan media internet sangat diperlukan guna menghindarkan anak-anak mereka terpapar pengaruh iklan pornografi yang terdapat pada media internet, orang tua wajib memberikan edukasi terhadap anak-anak mereka mengenai pengaruh buruk yang ditimbulkan dari internet khususnya pornografi.

Kecanduan pornografi sangat membahayakan bagi orang yang bersangkutan dan orang-orang disekitamya, salah satunya meningkatkan eksplorasi seks remaja sehingga dapat terjadi perilaku seks bebas dan perilaku seksual berisiko hal tersebut tentu saja dapat merusak tatanan norma-norma yang terdapat dalam masyarakat, dan dapat merusak keserasian hidup keluarga dan masyarakat. Selain itu kecanduan pornografi juga dapat merusak mental bagi seseorang yang sudah terpapar pengaruh pornografi.

Salah satu permasalahan sosial yang terjadi saat ini yaitu pornografi dikarenakan penggunaan media massa yang semakin meningkat dan hal ini memungkinkan penyebaran pornografi berupa foto maupun video di media elektronik. Cyberpornography tidak hanya bertentangan dengan norma, 
agama, kesusilaan, kesopanan, hukum namun juga merugikan dan merusak tatanan moral masyarakat (Frellina et al., 2021). Pada dasarnya ketentuan spesifik mengenai pornografi diatur dalam UU No. 44 Tahun 2008 tentang pornografi. Pada pasal 1 UU Pornografi menjelaskan bahwa pornografi adalah gambar, sketsa, ilustrasi, foto, tulisan, suara, bunyi, gambar bergerak, dan bentuk-bentuk pesan lainnya melalui berbagai bentukmedia komunikasi atau pertunjukan di muka umum, yang memuat kecabulan atau eksploitasi seksual yang melanggar norma kesusilaan dalam masyarakat (Hermawan, 2020). Lebih lanjut, Siregar \& Sihite (2021) Penegakan hukum pidana bagi pelaku penyebar konten pornografi di media sosial jika ditinjau dari UU Informasi dan Transaksi Elektronik Pasal 45 ayat 1 UU No 19 Tahun 2016 tentang ITE menjelaskan bahwa ancaman pelaku penyebaran dapat dipidana penjara maksimal 6 tahun dan denda Rp. 1.000.000.000 milyar.

Maka berdasarkan uraian diatas, tujuan dari penelitian pengaturan hukum mengenai lklan pornografi pada media sosial dan serta upaya pencegahan terhadap pelaku penyebaran iklan pada media elektronik yang memuat konten pornografi.

\section{METODE PENELITIAN}

Penelitian yang penulis gunakan adalah penelitian hukum normatif (Hartono, 1994) yaitu penelitian dilakukan dengan menganalisis peraturan perundang-undangan yang berlaku. Mengenai sumber bahan hukum yang digunakan terbagi atas Bahan Hukum Primer adalah bahan hukum yang utama yang menjadi dasar kajian dari penulisan penelitian ini. Bahan Hukum sekunder adalah adalah bahan hukum yang digunakan untuk menunjang atau membantu dalam memberikan pemahamanpemahaman dan gambaran-gambaran serta teori-teori hukum yang digunakan untuk mengulas dan memecahkan persoalan-persoalan yang akan di teliti di dalam penelitian penulisan skripsi. Selanjutnya Bahan Hukum Tersier adalah bahan hukum yang memberikan pedoman dan interpretasi bagi bahan hukum tingkat pertama dan kedua. Teknik pengumpulan bahan dalam penelitian menggunakan teknik studi pustaka (library research) yaitu membaca, mencatat, mengutip, meringkas, dan menelaah informasi data dari peraturan atau literatur yang terkait dengan masalah tersebut. Setelah bahan hukum telah terkumpul melalui proses studi pustaka, dalam menganalisis bahan hukum yang telah terkumpul dalam penelitian ini penulis menggunakan uraian teknis, sistematisasi, argumentasi dan interpretasi hukum berdasarkan logika deduktif dan induktif. Ditinjau sesuai kebutuhan dengan menggunakan pendekatan kualitatif. Selanjutnya setelah bahan hukum primer dan sekunder terkumpul, ini akan diolah dan dianalisis rnenggunakan metode penanganan bahan hukum yang sistematis (Bambang, 2002).

\section{HASIL DAN PEMBAHASAN}

\section{Pengaturan Hukum Mengenai lklan Pornografi Pada Media}

Perkembangan dari teknologi informasi dan teknologi yang terjadi saat ini merniliki segudang manfaat tentang pemanfaatan transaksi bisnis tetapi ada saatnya dunia virtual/maya hanya digunakan sebagai tempat seorang warganet atau pengguna internet hanya untuk berhubungan seperti dunia nyata. Dunia virtual/maya juga mempunyai masalah yang muncul diakibatkan dari penyalahgunaan kemajuan teknologi itu sendiri yang ujungnya menjadi masalah hukum. Masyarakat yang mengetahui tentang penyalahgunaan teknologi internet ujungnya ingin adanya peraturan yang jelas tentang dunia virtual/maya ini. problematika susila yang mulanya dirasa hanya terdapat dalam dunia nyata ujungnya banyak terbawa ke dunia virtual.

Korban dari perilaku asusila dalam dunia virtual/maya ini bisa saja anak-anak di bawah umur sampai remaja. Website pornografi yang tersebar di dunia virtual/maya menyebabkan pihak yang seharusnya tidak pas untuk mengaksesnya malah melakukan browsing ke situs itu. Problematika yang muncuJ karena adanya website pornografi, baik itu milik sekelompok orang yang berasal dari dalam negeri maupun sekelompok orang di luar negeri menjadikan masyarakat perlu awas terkait munculnya tingkah laku anak-anak maupun remaja di dalam keluarga mereka supaya tidak mengakses website pornografi tersebut.

Pengaturan penyebaran iklan pornografi rnelalui media internet telah diatur dalam Wetboek van Strafrecht (WvS) KUHP Indonesia, Tindak Pidana Pornografi diatur di dalam Bab XIV tentang kejahatan Terhadap kesusilaan dalam pasal 281-283 KUHP. Pornografi merupakan kejahatan yang termasuk golongan tindak pidana rnelanggar yang kesusilaan (redelijkheid). Tindak pornografi 
berkaitan dengan adat kebiasaan yang berhubungan dengan kelamin (seks) seseorang. Berlandaskan pasal tersebut serta pengertian tentang makna pornografi di masyarakat, timbul perubahan yang menggeser makna pornografi tersebut.

Perubahan arti yang diakibatkan oleh berkembangnya teknologi informasi sepaturnya rnengubah pengertian ten tang unsur pidana pornografi. Apabila menggunakan penafsiran lama, maka layar komputer yang terdapat pada rental komputer, kantor serta pribadi tidak bisa dimaksudkan sebagai makna di muka umum seperti dimaksudkan dalam Pasal 282 KUHP. Pada intinya apa yang dimaksud dengan di muka umum dalam hal ini harus ditafsirkan dengan lebihjelas sesuai pendekatan teknologi informasi tersebut.

Selain itu dalam Pasal 282 KUHP juga tidak disebutkan batas-batas kesusilaan dan juga yang dimaksud dengan kesusilaan itu sendiri. Disebutkan pad a bagian penjelasan, sifat cabul (kesusilaan) itu harus dinyatakan berdasar pendapat umum. Setiap peristiwa harus diamati masing-masing dan sangat tergantung dengan kebiasaan lokal. Dari sana dapat dilihat, bahwa tidak ada batas yang mutlak tentang pornografi atau perbuatan cabul tersebut. Batasnya hanya keadaan dan perkembangan dari masyarakat setempat. Selanjutnya pengaturan mengenai penyebaran iklan pornografi melalui internet telah diatur di dalam pasal Pasal 27 ayat I Undang-undang Nomor 11 Tahun 2008 tentang lnformasi dan Transaksi Elektronik atau yang biasa disebut dengan UU ITE, dalam Undang-Undang No. 11 Tahun 2008 tentang lnformasi dan Transaksi Elektronik sanksi pidana hanya dijatuhkan unruk setiap orang yang melakukan perbuatan seperti dinyatakan dalam pasal 27 ayat I yakni pidana penjara paling lama 6 (enam) tahun dan/atau denda paling banyak Rp 1.000.000.000,00 (satu miliar rupiah) (Moeljatno, 1993).

Pasal 27 ayat I Undang-undang Nomor 11 Tahun 2008 ini menyebutkan kata dapat diaksesnya. Berarti setiap orang yang dengan sengaja dan tanpa hak membuat dapat diaksesnya informasi elektronik bermuatan pornografi atau pelanggaran kesusilaan akan terkena sanksi pidana . Misalnya, seseorang mempunyai situs, jika dalam situs itu terdapat link (hubungan) ke situs lain yang rnemuat konten pornografi, maka orang tersebut bisa dikatakan serta merta menyebarkan pornografi arau membuatorang lain dapat mengakses situs pornografi. Kasus lain, perbuatan seseorang mengirim pesan lewat surat elektronik (sure) kepada orang lain dan memberitahukan tentang adanya situs pomografi yang dapat diakses, maka perbuatan orang tersebut juga tergolong sebagai penyebaran pornografi yang dimaksud dalam Undang-undang Nomor 11 Tahun 2008.

\section{Upaya Pencegahan Terhadap Pelaku Penyebaran Iklan Pada Media Elektronik Yang Memuat Konten Pornografi}

Upaya pencegahan yang dilakukan terhadap pelaku penyebaran iklan pada media elektronik yang memuat konten pomografi adalah dengan melakukan upaya preventif dan represif, dimana upaya preventif tersebut adalah seperti

a) Melakukan penyuluhan atau sosialisasi

Penyuluhan atau sosialisasi dapat dilaksanakan oleh kepolisian tentang sosialisasi serta mendidik masyarakat baik itu merupakan orang tua, pelajar, instansi terkait, organisasi, karang taruna, pemuda-pemudi dan yang lainnya secara insidental (Hanifah, 2013). Sosialisasi serta Pendidikan dimaksud berkaitan tentang aspek hukum yaitu mencakup sanksi serta peraturan tindak pidana pomografi, nilai kesusilaan dan nilai moral terhadap bahaya yang ditimbulkan pornografi.

b) Promosi stop kenakalan rernaja, pornografi dan prostitusi

Promosi stop kenakalan remaja, pornografi dan prostitusi ini dapat dilaksanakan dari pihak kepolisian dapat dilakukan dengan membuat banner, baliho, pamflet, leaflet, brosur, karikatur dan juga baliho di sekitar warung internet, sekolah, pinggir jalan, serta tempat umum lainnya dengan tujuan menambah kesadaran masyarakat.

c) Pencegahan melalui pendekatan agama dan sosial.

Pendekatan agama dan sosial dapat juga dilaksanakan sebagai upaya sosialisasi yang dapat dilaksanakan pihak kepolisian dengan tujuan menambah nilai-nilai agama, akhlak yang mulia para remaja serta anak-anak. Disamping itu, pihak kepolisian melakukan bimbingan sosial seperti pemberian edukasi dalarn hal tindak pidana pornografi.

d) Pemberian himbauan kepada orang tua agar lebih memperhatikan dan mengawasi anak-anaknya (Wahid \& Labib, 2005). Pengawasan orang tua sangat penting tentang pencegahan tindak pidana pornografi. Karena peran orang tua adalah mengajarkan anak-anaknya tentang perilaku yang baik. 
Maka dari iru jika pengawasan terhadap anak-anak dilakukan dengan benar, maka perilaku anakanak dapat diawasi dengan baik oleh orang tuanya, lalu dengan tidak langsung menekan angka tindak pidana pornografi.

e) Mencegah beredarnya kaset dan film porno di internet

Upaya pencegahan beredarnya kaset dan film porno di masyarakat dapat dilakukan pihak kepolisian dengan cara melakukan razia di tempat penjualan dan penyewaan kaset di pinggiran jalan dan juga tempat penjualan kaset secara resmi. Dengan dilakukannya razia secara tepat, maka akan dapat mencegah beredarnya kaset porno. Disamping itu juga polisi dapat melaksanakan pengaduan sirus atau halaman yang berisi muatan pornografi ke KEMENKOMINFO.

f) Menyertakan masyarakat dalam peran aktif untuk melaporkan tentang tindak pidana pornografi

Peran serta masyarakat dapat dilibatkan dalam hal memerangi penyebaran tindak pidana pornografi. Peran masyarakat sangat penting karena mereka sendiri yang mengetahui tentang ada atau tidaknya tindak pidana pornografi yang terjadi di masyarakat.

Selanjutnya mengenai upaya represif yang dilakukan aparat penegak hukum dalam menindak pelaku penyebaran iklan porno yang disebarkan melalui media sosial adalah melakukan beberapa upaya represif dari aparat penegak hukum karena banyaknya tindak pidana pornografi yang beredar di masyarakat membuat petugas penegak hukum dalam hal ini kepolisian dapat melaksanakan penindakan hukum dengan lebih aktif, dengan cara melaksanakan penyidikan dan penyelidikan terhadap hal-hal yang dicurigai sebagai tindak pidana pornografi. Baik yang

diadukan oleh masyarakat maupun yang tidak diadukan, dengan demikian dapat menangkap para pelaku yang melanggar Undang-Undang Nomor 44 tahun 2008 tentang Pomografi tanpa pandang bulu.

a. Sub Sistem Kepolisian

Dalam melaksanakan penyelidikan, polisi memiliki tujuan agar mendapatkan ternyata benar disana terdapat pelanggaran maka dapat dilakukan penyidikan. Dalam hal ini kepolisian bertugas rnelakukan penyidikan seperti yang disebutkan di dalam Pasal 23 Undang-undang Nomor 44 Tahun 2008 tentang Pomografi, yang mana penyidikan tentang tindak pidana pornografi dilakukan sesuai KUHAP ,kecuali diatur UU Pomografi. Pengecualian terhadap proses penyidikan oleh Polisi yang diatur di dalam undang-undang tersebut adalah sepeni yang disebutkan di dalam Pasal 24 sampai dengan Pasal 27. Penyidikan dilaksanakan untuk menemukan bukti, setelah itu dilanjutkan dengan proses pemeriksaan saksi dan korban atau tersangka yang mengalami secara langsung kejadian tindak pidana pornografi tersebut dengan tujuan untuk memperoleh secara jelas tentang peristiwa pidana yang telah terjadi menurut hasil penyelidikan serta penindakan sebelumnya. Dalam melaksanakan penyelidikan perkara tersebut ada 2 cara yang dilakukan yaitu dengan undercover chat dan undercover buy.

b. Sub Sistem Kejaksaan

Dalam subsistem kejaksaan ini bakal dilaksanakan proses penuntutan. Dalam hal ini bisa diketahui Penuntutan dilaksanakan oleh Penuntut umum, Penuntutan umum dalam hal ini melaksanakan penuntutan diawali dengan pra penuntutan yaitu dengan mengamati dan meninjau kembali Berita Acara Pemeriksaan (BAP) yang diberikan oleh penyidik termasuk menyiapkan surat dakwaan sebelum dilaksanakannya penuntutan. Apabila sudah terangkum maka bisa dilaksanakan penuntutan, yaitu berkas-berkas harus segera dilimpahkan ke Pengadilan Negeri dengan perrnintaan supaya secepatnya mengadili perkara tersebut beserta dengan surat dakwaan.

c. Sub Sistem Hakim

Jika kepada putusan suatu perkara pidana sudah dilaksanakan penuntutan, maka perkara itu dapat diajukan kepada pengadilan. Dalam tahapan ini akan dilakukan pemeriksaan-pemeriksaan berkenaan dengan saksi-saksi dan juga alat bukti yang berkenaan dengan tindak pidana pornografi. Dalam tahap ini, hakim saat memeriksa selain bersumber dari Undang-Undang Nomor 44 Tahun 2008 tentang pornografi di dalam Pasal 24 yang berkaitan dengan alat-alat bukti yang juga telah diuraikan sebagaimana juga bersumber dari Kitab Undang-Undang Hukum Acara Pidana.

d. Sub sistem Pemasyarakatan

Dalam subsistem ini dilakukan tata cara pelaksanaan putusan sebagai berikut (1) Mendapat salinan putusan pengadilan dari panitera pengadilan negeri yang bersangkutan dalam waktu I minggu, (2) Kepala kejaksaan mengeluarkan surat pemerintahan surat perintah pelaksanaan 
putusan pengadilan, (3) Menyerahkan terpidana pada lembaga pemasyarakatan, (4) Membuat laporan pelaksanaan. Berdasarkan pemaparan mengenai upaya preventif dan represif yang sudah dijelaskan diatas, sangat penting dalam upaya menanggulangi penyebaran iklan pornografi pada media sosial yang berpotensi merusak kesehatan rohani maupun jasmani baik dari generasi muda maupun golongan orang dewasa agar terhindar dari pengaruh buruk yang ditimbulkan akibat iklan pornografi yang disebarkan melalui media sosial, sehingga upaya preventif dan represif diperlukan guna menanggulangi penyebaran iklan pornografi yang sangat pesat di media sosial. Diperlukan peran serta dari masyarakat dan aparat penegak hukum untuk bersinergi bersama dalam hal memerangi penyebaran iklan porno pada media sosial yang dilakukan oleh pihak yang tidak bertanggungjawab.

\section{SIMPULAN DAN SARAN}

\section{Simpulan}

Berdasarkan penjelasan pada bab-bab sebelumnya, maka penulis dapat menarik kesimpulan bahwa pengaturan dari penyebaran iklan pada media elektronik yang memuat konten pornografi dapat ditemukan dalam Undang-Undang Nomor 11 Tahun 2008 tentang lnformasi dan Transaksi Elektronik (ITE), yaitu pasal 27 ayat (I), pasal 35, pasal 50, dan pasal 51 ayat (I). Sernentara itu, pengaturan tentang pornografi secara umum juga dapat ditemukan dalam Kitab Undang-Undang Hukum Pidana (KUHP) yaitu pasal 281-283 tentang kejahatan terhadap kesusilaan. Adapun upaya penanggulangan yang dapat dilakukan untuk menekan penyebaran iklan pada media elektronik yang memuat konten pornografi adalah dengan upaya preventif (non penal), dan represif. Upaya preventif dapat dilakukan dengan melakukan penyuluhan atau sosialisasi promosi stop kenakalan remaja, pornografi dan prostitusi pencegahan melalui pendekatan agama dan sosial Memberi sosialisasi kepada orang rua supaya lebih mengawasi dan memperhatikan anak-anaknya Mencegah peredaran kaset dan film pornografi di internet menyertakan masyarakat untuk lebih aktif mengadu jika terdapat tindak pidana pornografi. Sedangkan upaya preventif dapat dilakukan dengan melibatkan Sub Sistem Kepolisian, Subsistem Kejaksaan, Sub sistem Hakim, Sub sistem Pemasyarakatan.

\section{Saran}

Pada penelitian ini terdapat saran yang ditujukan dari berbagai kalangan. Untuk pemerintah dapat lebih memperhatikan mengenai kejahatan-kejahatan yang berkaitan dengan pornografi sehingga dapat menekan terjadinya kejahatan pornografi yang dapat merusak mental generasi penerus bangsa. Untuk masyarakat terutama orang tua hendaknya lebih memperhatikan anak-anaknya dan membimbingnya dan menjauhkannya dari hal-hal yang dapat merusak mental dan masa depannya seperti pornografi.

\section{DAFTAR PUSTAKA}

Bambang, S. (2002). Metodologi Penelitian Hukum. PT Grafindo Persada, Jakarta.

Chazawi, A., \& Ferdian, A. (2015). Tindak Pidana Pers Penyerangan Terhadap Kepentingan Hukum yang Dilindungi dengan Mempublikasikan Tulisan. Mandar Maju. Bandung.

Frellina, A. R. C., Amatullah, N., \& Azizah, S. N. (2021). Pengaturan Cyberpornography berdasarkan UU ITE dan UU Pornografi. Jurnal Kertha Semaya, 9(5), 793-804.

Hamzah, A. (1989). Aspek-aspek Pidana di Bidang Komputer. Sinar Grafika, Jakarta.

Hanifah, I. R. U. (2013). Kejahatan Pornografi Upaya Pencegahan dan Penanggulangannya di Kabupaten Ponorogo. Justitia Islamica, 10(2), 331-358.

Hartono, S. (1994). Penelitian Hukum di Indonesia pada Akhir Abad ke-20. Alumni, Bandung.

Hermawan, A. N. (2020). Penyebaran Konten Pornografi Melalui Media Elektronik ditinjau dari Undang-undang Informasi dan Transaksi Elektronik Juncto Undang-undang Pornografi. Jurnal Education and Development, 8(4), 669-673.

Moeljatno. (1993). Azas-azas Hukum Pidana. Rineka Cipta, Jakarta.

Siregar, G. T. ., \& Sihite, I. P. S. (2021). Penegakan Hukum Pidana bagi Pelaku Penyebar Konten Pornografi di Media Sosial ditinjau dari Undang-Undang Informasi dan Transaksi Elektronik. Jurnal Rectrum, 3(1), 1-11. 
Jurnal Interpretasi Hukum

Vol. 2, No. 2, 2021

Wahid, A., \& Labib, M. (2005). Kejahatan Mayantara (Cyber Crime). Refika Aditama, Bandung. 